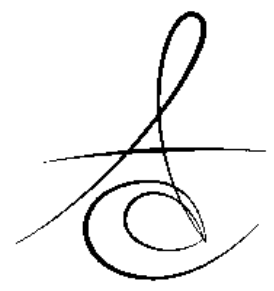

\title{
EVALUATION OF MAXILLARY CANINE CALCIFICATION AND SKELETAL MATURITY COMPARING MALES AND FEMALES SUBJECTS IN DIFFERENT FACIAL HEIGHTS
}

\section{FARKLI YÜZ YÜKSEKLİĞİNE SAHİP ERKEK VE KIZ HASTALARDA MAKSİLLER KANİN KALSİFÍKASYONU VE İSKELETSEL MATURASYONUN DEĞERLENDİRİLMESİ}

\author{
Dr. Öğr. Üy. Emel ONCAN*
}

Dr. Öğr. Üy. Seden AKAN*

\author{
Makale Kodu/Article code: 4509 \\ Makale Gönderilme tarihi: 19.07 .2020 \\ Kabul Tarihi: 06.11.2020 \\ DOI : $10.17567 /$ ataunidfd. 822459
}

Emel Oncan: ORCID ID: 0000-0003-3654-5451

Seden Akan: ORCID ID: 0000-0001-7955-3086

\section{ABSTRACT}

Aim: The aim of the study is to evaluate skeletal maturity and calcification stages of maxillary canines, in relation to vertical, normal and horizontal facial types in females and males.

Material and Method: The sample consisted of 60 patients (30 females and 30 males), with skeletal Class I malocclusion. The subjects were divided into a high-angle group, a low-angle group, and a normal-angle group. Cervical vertebral maturity index (CVM) and Demirjian index (DI) were used to assess the cervical vertebrae maturation level and calcification stages of maxillary canines.

Results: CVM stages of the low angle group were found to show a higher tendency for CVM4 in the female group ( $r=0.484)$ than in the male group $(r=0.439)$. However, in the high angle group, a higher tendency for CVM6 stage was found in the female group $(r=-1.014)$, and a higher tendency of CVM5 was observed in the male group $(r=0.00)$. The median value of maxillary canine DI stage is stage $\mathrm{F}$ in the low-angle and normal-angle groups and $\mathrm{G}$ in the high angle group. The DI stages of maxillary canines in the male group are left skewed $(r=-1.035)$, which means that there is a tendency toward low values of maxillary canine DI stages. The DI stages of maxillary canines in the female group are right skewed $(r=0.0911)$, implying that there is a slight tendency toward high values of maxillary canine DI stages.

Conclusion: Comparisons between the sexes and facial heights revealed that cervical maturity and tooth calcification stages of maxillary canines are more advanced in females and in the high angle group.

Keywords: Cervical Vertebra, Tooth Calcification, Cephalometry, Dental Radiography

öz

Amaç: Bu çalışmanın amacı kız ve erkek bireylerde uzun, normal ve kısa yüz tiplerine göre, iskeletsel maturasyon ve maksiller kanin diş kalsifikasyon ilişkisini değerlendirmektir.

Gereç ve Yöntem: Örneklem grubu Sınıf I maloklüzyona sahip, 9-13 yaş aralığında 60 bireyden (30 kIz ve 30 erkek) oluşturulmuştur. Bireyler uzun yüz büyümesi, normal yüz büyümesi ve kısa yüz büyümesi olmak üzere 3 gruba ayrıarak; servikal vertebral maturasyon evrelerinin değerlendirmesi için Servikal vertebral maturasyon indeksi (CVM), maksiller kanin dişlerin kalsifikasyon aşamalarını değerlendirmek için Demirjian İndeksi (DI) kullanılmışır.

Bulgular: Kısa yüz büyümesine sahip bireylerde CVM evrelerinden CVM4 görülme oranı kızlarda $(r=0.484)$ erkeklere $(r=0.439)$ oranla daha yüksektir. Bununla birlikte uzun yüz büyümesi olan hastalarda ise, kızlarda CVM6 evresinde $(r=-1.014)$, erkeklerde $(r=0.00)$ ise CVM5 evresinde yoğunluk fazla bulunmuştur. Normal büyüme ve kısa yüz büyümesi gruplarında maksiller kanin dişin DI evresi ortancası $\mathrm{F}$ döneminde iken, uzun yüz grubunda ise $\mathrm{G}$ dönemindedir. Erkek grubunda maksiller kaninin DI evresi sola eğimli $(r=-1.035)$ bulunmuştur, bu durum daha düşük evrelere eğilim olduğu anlamına gelir. Kız grubunda ise maksiller kaninin DI evresi sağa $(r=0.0911)$ eğimlidir, bu durum daha yüksek evrelere eğilim olduğu anlamına gelir.

Sonuç: Cinsiyetler ve yüz yükseklikleri arasındaki karşılaştırmalar, maksiller kanin dişlerde kalsifikasyon ve servikal olgunluk aşamalarının kızlarda ve uzun yüz büyümesi olan grupta daha ileri olduğunu ortaya koymuştur.

Anahtar Kelimeler: Servikal vertebra, Diş kalsifikasyonu, Sefalometri, Dental Radyografi

${ }^{*}$ Altınbaş University, Vocational School of Health Services, Istanbul.

** Altınbaş University, Faculty of Dentistry, Departments of Orthodontics, Istanbul

Kaynakça Bilgisi: Oncan E, Akan S. Farklı yüz yüksekliğine sahip erkek ve kız hastalarda maksiller kanin kalsifikasyonu ve iskeletsel maturasyonun değerlendirilmesi. Atatürk Üniv Diş Hek Fak Derg 2021; 31: 15-21.

Citation Information: Oncan E, Akan S. Evaluation of maxillary canine calcification and skeletal maturity comparing males and females subjects in different facial heights. J Dent Fac Atatürk Uni 2021; 31: 15-21. 


\section{INTRODUCTION}

Age ascertainment has great significance in the treatment of growing orthodontic patients. Clinicians should determine the patients' growth status so that an appropriate treatment can begin in a timely fashion. ${ }^{1}$ In orthodontic patients, it is essential to assess whether pubertal growth has started, is ongoing, or has finished. ${ }^{2}$ Chronologic age is not, on its own, adequate to assess the stages of development of a growing child. Differences between chronological and biological age have led to the use of such growth indicators of maturity as skeletal age, morphological age, sexual age, and dental age. ${ }^{3}$

The cervical vertebral maturity index (CVM), introduced by Hassel and Farman, ${ }^{4}$ is a beneficial method to assess the skeletal maturation; it utilizes the morphology of the cervical vertebrae to determine the growth potential of an individual. It was later revised by Baccetti et al., ${ }^{5}$ who concentrated on the three cervical vertebrae $(\mathrm{C} 2, \mathrm{C} 3, \mathrm{C} 4)$, and they assessed based on the shape and presence of a recess at the lower border of the cervical vertebrae.

Dental growth is also a beneficial tool to measure maturity. Calcification of the teeth is a more dependable indicator of dental maturity than tooth eruption. As tooth eruption may be influenced by various elements, such as early missing of primary teeth, space deficiency, dental caries, ankylosis, in addition to being under genetic and hormonal control, 6,7 numerous methods have been used to assess dental maturity. Demirjian Index (DI) ${ }^{6}$ is one of the most used methods to determine dental age because of its simplicity. This method is based on the development of seven left permanent mandibular teeth. Most of the studies using Demirjian's method have reported overestimation 7,8 and, for Turkish population, there are studies have showed both overestimation ${ }^{9,10}$ and convenient. ${ }^{11}$

Several studies have confirmed the existence of a positive relationship between calcification stages of the tooth and skeletal maturation stages. ${ }^{12,14}$ Moreover, it is also known that there is a relationship between vertical growth direction and skeletal maturity. ${ }^{5,12,13,15,16}$ Baccetti et al. ${ }^{5}$ stated that eruption of teeth completed an earlier stage in hyperdivergent subjects. Perinetti et al. ${ }^{15}$ also found that patients with a vertical facial type had earlier dental maturation. Nanda ${ }^{16}$ reported that the growth spurt period was faster in an open-bite group than in the deep-bite group. Lee et al. ${ }^{13}$ pointed out that orthodontic treatment in women with a high mandibular angle can be started earlier than in women with a low mandibular angle. To the best of our knowledge, there is no other study that evaluates the relationship between skeletal maturity stages and dental calcification stages in different facial heights of female and male subjects.

The purpose of this study is to evaluate whether there are differences in the calcification stages of maxillary canines and cervical vertebrae maturity in high, normal and low facial heights, in both sexes.

\section{MATERIALS AND METHODS}

The protocol of this retsospective study was reviewed and approved by the local ethical commitee of (No: 2020/7, 28 thMay2020). Signed informed consent of the patients treated at the Department of Orthodontics in between 2018 December and 2020 January was obtained. This study was conducted on 60 subjects who visited of Orthodontics: 30 females and 30 males (a power analysis was performed with G-power 3.1 (Erdfelder, Faul, \& Buchner, 1996)) and 55 subjects were found to be sufficient ( $a=0.05$, $f=0.37$, power $=0.80$ ), with ages ranging from 9 to 13 years. The mean age of the females was $11.98 \pm 1.04$ years and the mean age of the males was $11.97 \pm 0.98$. The inclusion criteria for the study were as follows: no craniofacial anomalies, no systemic muscle or joint disorders, no dental development problems, good quality cephalometric and panoramic radiographs, and Class I malocclusion (ANB angle, 2.0 to $4.0^{\circ}$; Wits: 2.5 to $5.26 \mathrm{~mm}$ ).

The study sample was divided into to three groups, according to the mandibular plane angle to the anterior cranial base (SN-GoMe): low angle group (mandibular plane angle $<33.0^{\circ}$ ); normal angle group $\left(33.0^{\circ} \leq\right.$ mandibular plane angle $\left.<41.0^{\circ}\right)$; and high angle group (mandibular angle $\geq 41.0$ ). All analyses were performed by an experienced orthodontist. The calcification stages of the canine were assessed according to the method of Demirjian, ${ }^{6}$ in which one of eight stages of calcification ( $A$ to $H$ ) is assigned to the tooth. Evaluation of skeletal maturity stage was done using the cervical vertebral maturation index (CVM), as revised by Baccetti et al., ${ }^{5}$ on the lateral cephalograms. The second, third and fourth cervical vertebrae (C2, C3 and C4) were divided into 6 stages in CVM according to their shapes. 


\section{Statistical Analysis}

Analysis of the data was performed using the package program SPSS 16 (SPSS for Windows, SPSS Inc, Chicago, Ill., USA). An independent sample t-test was performed to evaluate chronological ages. The between-group differences of the CVM and DI stages were evaluated by performing the Kruskal-Wallis $\mathrm{H}$ Test, and the relationships between CVM stages and vertical growth groups were evaluated by a Pearson correlation coefficient. To determine intrarater reliability, repeated determination was carried out on 10 individuals at an interval of 15 days, and Pearson correlation coefficients were calculated as being in the range of $0.750-0.880$. Statistical significance was set at $\mathrm{p}<0.05$.

\section{RESULTS}

There was no statistically significant difference observed between male and female patients, in terms of chronological ages $(p=0.940)$. Angular and linear cephalometric measurements of the groups were shown in Table-1.
A strong positive correlation was observed between SN-GoMe, DI stages of the maxillary canine, and CVM in all groups, according to the Pearson's correlation coefficient test (Table-2).

According to the results of the Kruskal-Wallis $\mathrm{H}$ test, there were statistically significant differences between CVM stages of the high angle, low angle, and normal angle groups ( $p$-value $=0.000<0.05$ ). Furthermore, statistically significant differences were observed between the low angle and high angle groups ( $p$-value $=0.00<0.05$ ), between the high angle and normal angle groups ( $p$-value $=0.001<0.05)$, and between the low angle and normal angle groups ( $p$ value $=0.011<0.05$ ). In addition, the Kruskal-Wallis $\mathrm{H}$ test was also performed to compare DI stages of maxillary canines between the low angle, high angle, and normal angle groups. A statistically significant difference was observed between the low angle and high angle groups ( $p$-value $=0.011<0.05)($ Table- 3 ).

It was observed that the CVM stages of the patients in low angle group are right-skewed, with skewness statistics of 0.484 and 0.439 for female and male groups, respectively. Further, it is worth noting

Table 1. Comparison of the angular and linear cephalometric measurments of the groups. One-way analysis of variance with Bonferroni post-hoc test was performed. ${ }^{* * *} \mathrm{p}<0.001{ }^{*} \mathrm{p}<0.05$. L: Low angle, $\mathrm{H}$ : High angle, $\mathrm{N}$ : Normal angle

\begin{tabular}{|c|c|c|c|c|c|c|c|c|c|c|}
\hline & \multicolumn{2}{|c|}{ Normal angle $(n=20)$} & \multicolumn{2}{|c|}{ Low angle $(n=20)$} & \multicolumn{2}{|c|}{ High angle $(n=20)$} & \multicolumn{2}{|c|}{ Total $(n=60)$} & \multirow[b]{2}{*}{ p_value } & \multirow[b]{2}{*}{ post hoc } \\
\hline & Mean & Std.dev. & Mean & Std.dev. & Mean & Std.dev. & Mean & Std.dev. & & \\
\hline SNA $\left({ }^{\circ}\right)$ & 80.58 & 3.20 & 81.70 & 3.12 & 77.73 & 3.57 & 80.05 & 3.66 & $<0.001^{* * *}$ & $\mathrm{~L}>\mathrm{N}>\mathrm{H}$ \\
\hline$S N B\left({ }^{\circ}\right)$ & 78.15 & 3.71 & 80.05 & 3.85 & 73.76 & 3.80 & 77.40 & 4.58 & $<0.000 * * *$ & $\mathrm{~L}>\mathrm{N}>\mathrm{H}$ \\
\hline$A N B\left({ }^{\circ}\right)$ & 2.92 & 2.37 & 2.05 & 4.05 & 3.97 & 2.35 & 2.95 & 3.12 & 0.139 & \\
\hline Wits(mm) & -0.14 & 3.11 & 0.15 & 5.13 & 0.11 & 4.91 & 0.04 & 4.43 & 0.976 & \\
\hline$S N-G o M e\left({ }^{\circ}\right)$ & 35.50 & 1.86 & 27.58 & 4.32 & 47.31 & 6.30 & 37.95 & 6.98 & $<0.000 * * *$ & $\mathrm{H}>\mathrm{N}>\mathrm{L}$ \\
\hline
\end{tabular}

Table 2. Correlation coefficients between CVM, DI stages of maxillary canine, SN-GoMe** Correlation is significant at the 0.01 level (2-tailed) *Correlation is significant at the 0.05 level (2-tailed).

\begin{tabular}{|l|l|l|l|}
\hline & CVM & DI Stages of Maxillary Canine & SN-GoMe \\
\hline CVM & 1 & $0.479^{* *}$ & $0.634^{* *}$ \\
\hline DI Stages of Maxillary Canine & & 1 & $0.281^{*}$ \\
\hline SN-GoMe & & & 1 \\
\hline
\end{tabular}

Table 3. Comparing the median and ranges of CVM stages and DI stages of maxillary canine of the three groups (normal angle-low angle- high angle). Kruskal-Wallis $\mathrm{H}$ test was performed.; $* 0.05 \geq \mathrm{p}$-value; $* * 0.01 \geq \mathrm{p}$-value; $* * * 0.001 \geq \mathrm{p}$-value

\begin{tabular}{|l|c|c|c|l|l|l|}
\hline & $\begin{array}{l}\text { Low Angle } \\
\mathbf{( N = 2 0 )}\end{array}$ & $\begin{array}{l}\text { High Angle } \\
\mathbf{( N = 2 0 )}\end{array}$ & $\begin{array}{l}\text { Normal Angle } \\
(\mathbf{N}=\mathbf{2 0})\end{array}$ & $\begin{array}{l}\text { Normal Angle/ } \\
\text { Low Angle } \\
\text { P-Value }\end{array}$ & $\begin{array}{l}\text { Low Angle/ } \\
\text { High Angle } \\
\text { P-Value }\end{array}$ & $\begin{array}{l}\text { High } \\
\text { Normal Angle } \\
\text { P-Value }\end{array}$ \\
\hline CVM Stages & $3(2-4)$ & $5(4-6)$ & $4(3-5)$ & $0.011^{* *}$ & $0.00^{* * *}$ & $0.001^{* *}$ \\
\hline $\begin{array}{l}\text { DI Stages } \\
\text { (Max.Canin) }\end{array}$ & $\mathrm{G}(\mathrm{E}-\mathrm{H})$ & $\mathrm{G}(\mathrm{F}-\mathrm{H})$ & $\mathrm{G}(\mathrm{F}-\mathrm{H})$ & & $0.011^{* *}$ & \\
\hline
\end{tabular}


that that there is a higher frequency of the CVM4 stage for the female group, relative to the male group. On the other hand, in the high angle group, CVM stages of the female group were observed to be left skewed $(r=-0.484)$, while CVM stages of the male group can be considered as symmetric $(r=0.00)$. Moreover, it was observed that there are more CVM6 stages in the female group than the in the male group. Finally, in the normal-angle group, the CVM stages in female group are left-skewed $(r=-1.014)$, whereas the CVM stages in the male group are rightskewed $(r=1.153)$. Moreover, it is possible to observe that the frequency of CVM5 stages in the female group is much higher than those in the male group, whereas the frequency of CVM3 stages in the male group is higher than those in the female group (Figure-1).

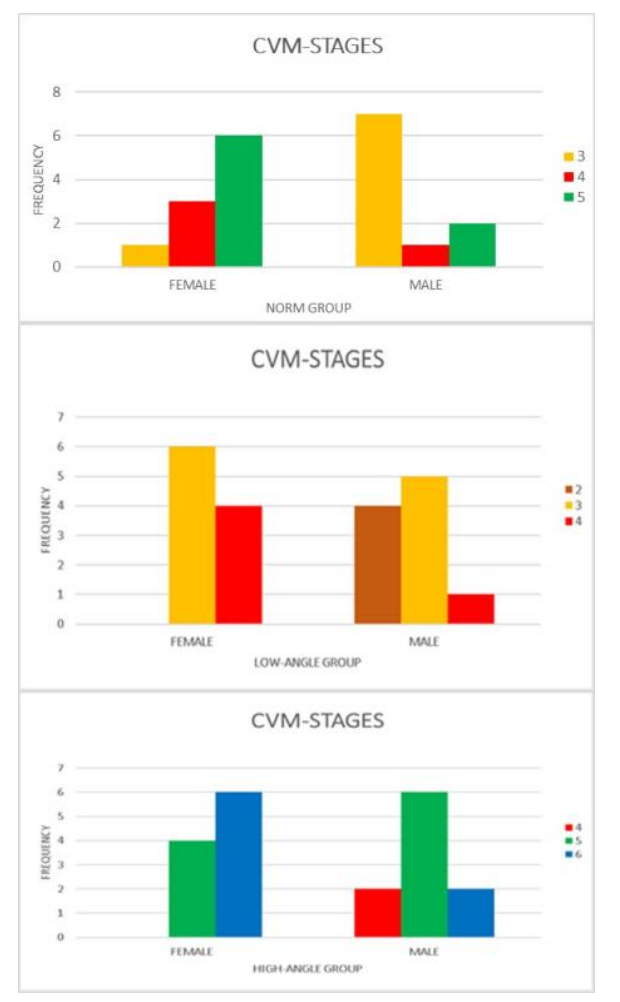

Figure 1. CVM stages for female and male patients of the groups (A- Low angle group, B- High angle group, C- Norm group).

Figure 2 presents the frequencies of DI stages of the maxillary canine for both sexes in all groups (low angle, high angle and normal angle groups). For the patients in the low angle group, minimum and maximum DI stages are, respectively, stages $\mathrm{E}$ and $\mathrm{H}$. Both median and mode are at stage F. In the low angle group, the maxillary canine DI stages are left skewed in both female $(r=-0.660)$ and male groups $(r=-0.438)$, which implies that there is a tendency for high values of the maxillary canine DI stages in both female and male groups. Moreover, there are 3 observations in stage $\mathrm{H}$ in the female group, whereas none of the male patients are in stage $\mathrm{H}$.

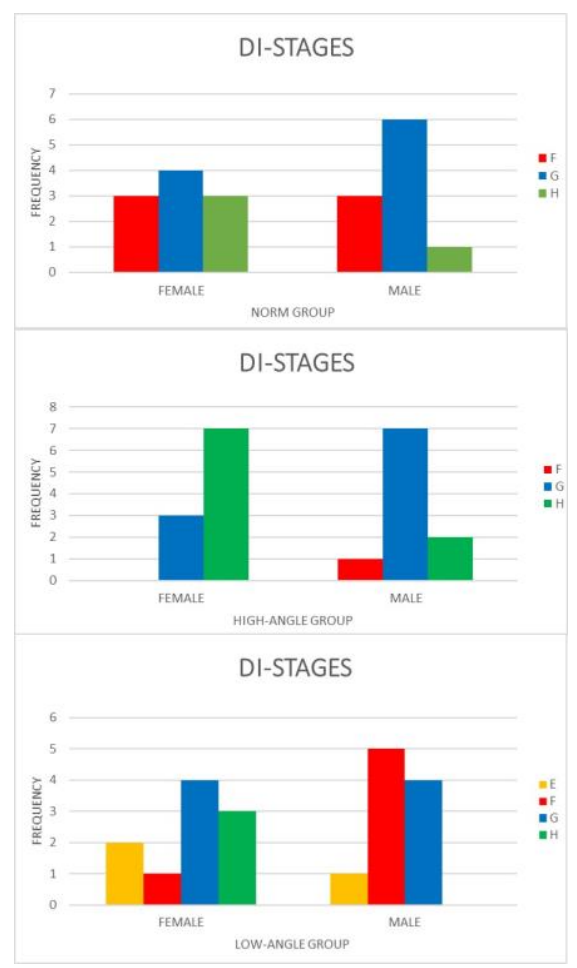

Figure 2. DI stages for female and male patients of the groups (A- Low angle group, B- High angle group, C- Normal group).

On the other hand, for the patients in the high angle group, minimum and maximum DI stages of the maxillary canine are, respectively, stage $F$ and stage $\mathrm{H}$. Both median and mode are at stage G. The DI stages in the male group are left skewed ( $r=-1.035)$, which means that there is a tendency toward low values of DI stages. The DI stages in the female group are right skewed $(r=0.0911)$, implying that there is slight tendency toward high values of DI stages.

Finally, for the patients in the normal angle group, minimum and maximum DI stages of the maxillary canine are, respectively, E and G. Both median and mode at stage $F$. The skewness of the maxillary canine DI stages in the female (male) group is $0.215(0.123)$, and they are right skewed. As both 
skewness statistics are positive, it can be stated that, for female and male groups, there is a tendency toward low DI stages of the maxillary canine.

\section{DISCUSSION}

In treatment planning and interceptive orthodontic diagnosis, skeletal maturity assessment and growth prediction is extensive tools. Chronological age is not a decisive factor in the evaluation of growth potential. ${ }^{17}$

The literature shows that there is a correlation between dental maturity and skeletal maturity. ${ }^{12,18,19}$ One of the most important indicators of skeletal maturity is dental maturity. Dental maturity is estimated through the stages of calcification, and this is a much more dependable method for the assessment of skeletal maturity. ${ }^{18}$

For many years, it has been known that girls mature earlier than boys. ${ }^{20}$ Additionally, females show an advanced developing dentition and female subjects attained skeletal maturity, on average, one year before male subjects. ${ }^{21,22}$ On the other hand, individuals show discrepancies in skeletal maturity, depending on anteroposterior or vertical facial types. Several studies have assessed the relationship between facial heights and skeletal maturity. 5,12,13,15,16

This study evaluated skeletal maturity and dental maturity and compared them in low-angle and high-angle females and males. The groups of this study were categorized based on the mandibular plane angle, because the mandibular plane angle is a simple and reliable analytical tool. Previous studies also categorized the groups based on the ratio of lower anterior facial height to anterior facial height, which is the Jarabak ratio. ${ }^{23,24}$

In the present study, skeletal maturity (CVM) showed a significant positive correlation with the mandibular plane angle (SN-GoMe) in all groups. It can be noted that the maturity of the cervical vertebrae correlates with the mandibular plane angle. These findings differ from those of Lee et al., ${ }^{13}$ which demonstrated a low correlation between CVM and mandibular plane angle. On the other hand, a strong positive correlation is observed between maturation stages of canines and mandibular plane angle. These results are similar to findings of Janson et al.. ${ }^{24}$ observing the relation between dental maturation and vertical facial types.

Lee et al. ${ }^{13}$ evaluated skeletal maturity in the cervical vertebrae and hand-wrist concerning vertical facial types in females. They discovered that the skeletal maturity of the hand-wrist in females with a high mandibular plane angle was higher than that of females with a low mandibular plane angle. Bacceti et al. ${ }^{5}$ stated that dental maturation occurs earlier in subjects with an extreme vertical facial type. Perinetti ${ }^{15}$ also pointed out that maxillary canine eruption was earlier in hyper-divergent subjects in contrast to hypo-divergent subjects. These results are similar to our results. The frequency distribution of maxillary canine DI stages was recognized to show a tendency for lower DI stages in the low angle group, whereas while there was a higher tendency for higher DI stages in high angle group in this study. However, maxillary canine calcification stages of female subjects are earlier than those of male subjects. The median and mode maturation stages of maxillary canine were observed to be at stage $F$ in the low angle group, whereas it was stage $G$ in the high angle group. Besides, DI stages of the maxillary canines were observed to have a high frequency in stage $\mathrm{H}$ in the low angle and high angle groups of females, whereas there was no stage $\mathrm{H}$ found in the low angle group of males, and $\mathrm{H}$ stage was observed to have a low frequency in the high angle group of males. This shows that tooth eruption may occur earlier in female and high angle subjects.

Kim et al. ${ }^{25}$ showed that there was no correlation between skeletal maturity and anteroposterior facial type or slightly delayed tendency in skeletal Class II. On the other hand, Jamroz et al. ${ }^{26}$ studied the link between vertical growth pattern and dental maturation in children with long and short anterior facial height and concluded that the variation in dental age between long and short facial types was statistically insignificant. However, Verulkar et al. ${ }^{27}$ showed patients with horizontal growth pattern had had delayed dental maturation when compared to vertical growers, also, Nanda ${ }^{28}$ and Janson ${ }^{24}$ reported that long face subjects presented a tendency to have advanced dental maturation. As such, there is a difference of opinion among the literature. ${ }^{24-28}$ When frequencies of CVM stages were evaluated in the high angle group, high frequency is observed at CVM5 stages in the male group, whereas in the female group, this high frequency is observed at CVM6. It can be concluded that skeletal maturation of high angle group female subjects is earlier than those of high angle male subjects. 
In conclusion, the limitation of this study is that the sample consisted of a single university orthodontic department, which is a very small number to use in a retrospective cross-sectional study. Further assessment of the relation between the different facial heights, skeletal maturity, and dental maturity requires larger samples.

\section{CONCLUSION}

Skeletal maturity and maxillary canine calcification stages can be influenced by facial heights and gender. Higher skeletal maturity and maxillary canine teeth calcification were observed in stages in high angle subjects and females, relative to low angle subjects and males. That is why, before deciding on orthodontic treatment, it may be worth considering starting treatment earlier in high angle subjects and females than in low angle subjects and males.

Acknowledgements
Funding
The authors declare that they have not received funding.
Availability of data and materials
The data supporting the conclusions of this article are
included within the article. The authors declare that the materials of
the article are available and suppliers of data were from Altınbaş
University, Faculty of Dentistry.
Conflicts of Interest
The authors declare that they have no conflict of interests.

\section{REFERENCES}

1. Rasool G, Hussain U, Shah SS. Evaluation of the skeletal maturation using lower canine mineralization. Pak Oral Dental J 2014;34:629-34.

2. Nolla CM. The development of permanent teeth. J Dent Child 1960;27:254-66.

3. Proffit WR. Contemporary Orthodontics. 5th ed. St. Louis: Mosby; 2013.

4. Hassel B, Farman AG. Skeletal maturation evaluation using cervical vertebrae. Am J Orthod Dentofacial Orthop 1995;107:58-66.

5. Baccetti T, Franchi L, McNamara JAJr. The cervical vertebral maturation (CVM) method for the assessment of optimal treatment timing in dentofacial orthopedics. Semin Orthod 2005; 11: 119-29.

6. Demirjian A, Goldstein H, Tanner JM. A new system of dental age assessment. Hum Biol 1973;45:21127.

7. Pandey M, Hamdani S, Ali SM, Goswami S, Rajpara.
Dental age assessment of 7 to 15 years-old children of Rajasthan using Demirjian's method. Indian J Dent Res Rev 2012;8-10.

8. Leurs IH, Wattel E, Aartman IH, Etty E, Prahl-Andersen B. Dental age in Dutch children. Eur J Orthod 2005;27:309-14.

9. Ozveren N, Serindere G. Comparison of the applicability of demirjian and willems methods for dental age estimation in children from the thrace region, Turkey. Forensic Sci Int 2018; 285:38-43.

10. Celikoglu M, Cantekin K, Ceylan I. Dental age assessment: the applicability of Demirjian method in eastern Turkish children. J Forensic Sci 2011;56:220-22.

11. Apaydin B K, Yasar F. Accuracy of the demirjian, willems and cameriere methods of estimating dental age on turkish children. Niger J Clin Pract 2018; 21:257-63.

12.Kamal A, Shaikh A, Fida M. Assessment of skeletal maturity using the calcification stages of permanent mandibular teeth. Dental Press J Orthod 2018;23:44E1-E8.

13.Lee YS, Choi SH, Kim KH, Hwang CJ. Evaluation of skeletal maturity in the cervical vertebrae and hand-wrist in relation to vertical facial types. Korean J Orthod 2019;49:319-25.

14.Bolanos MV, Manrique MV, Bolanos MJ, Briones MT. Approaches to chronological age

assessment based on dental calcification. Forensic Sci Int 2000;110:97-106.

15.Perinetti G, Callovi M, Salgarello S, Biasotto M, Contardo L. Eruption of the permanent maxillary canines in relation to mandibular second molar maturity. Angle Orthod 2013;83:578-83

16.Nanda SK. Patterns of vertical growth in the face. Am J Orthod Dentofacial Orthop 1988;93:103-16.

17.Sachan K, Sharma VP, Tandon P.A correlative study of dental age and skeletal maturation. Indian J Dent Res 2011;22:882-5.

18.Džemidžić V, Tiro A, Zukanović A, Redžić I, Nakaš E. Skeletal maturity assessment using mandibular canine calcification stages. Acta Medica Academica 2016;45:128-34.

19.Kumar S, Roy AS, Garg A, Hamid SB, Tyagi S, Kumar A. Correlation between maxillary canine calcification and skeletal maturation. J Clin Diagn Res 2017;11:ZC13-6.

20. Graber LW, Vanarsdall RL, Vig KW, Huang GJ. Orthodontics: current principles and techniques. New York: Elsevier Health Sciences; 2016. 
21. Esenlik E, Atak A, Atlun C. Evaluation of dental maturation in children according to sagittal jaw relationship. Eur J Dent 2014;8:38-43.

22. Kurita LM, Menezes AV, Casanova MS, Haiter-Neto F. Dental maturity as an indicator of

chronological age: radiographic assessment of dental age in a Brazilian population. J Appl Oral Sci 2007;15:99-104.

23. Neves LS, Pinzan A, Janson G, Canuto CE, de Freitas MR, Cançado RH. Comparative study of the maturation of permanent teeth in subjects with vertical and horizontal growth patterns. Am J Orthod Dentofacial Orthop 2005;128:619-23.

24. Janson GR, Martins DR, Tavano O, Dainesi EA. Dental maturation in short and long facial types. Is there a difference? Eur J Orthod 1998;20:73-8.

25. Kim KH. A longitudinal study on the skeletal maturity of the hand and wrist among various malocclusion groups (I) Korean J Orthod 1999;29:183-95.

26. Jamroz GM, Kuijpers-Jagtman AM, van't Hof MA, Katsaros C. Dental maturation in short and long facial types. Is there a difference? Angle Orthod 2006;76:768-72.

27. Verulkar A, Singla P, Patil HA, Tekale PD. Assessment of skeletal and dental maturity indicators and comparison of maturity indicators in vertical and horizontal growth pattern individuals with normal growth pattern individuals. Int ] Orthod Rehabil 2017;8:108-11

28. Nanda SK. Patterns of vertical growth in face. Am J Orthod Dentofacial Orthop 1988;93:103-16.

\section{Sorumlu Yazarın Yazışma Adresi Seden Akan}

Altınbaş Üniversitesi Diş Hekimliği Fakültesi

Zuhuratbaba Mahallesi, İncirli Caddesi, No:11-A 34147 Bakırköy / İstanbul / Turkey

Mobile phone: 00905355113760

E-mail: sedenakandt@hotmail.com 